\title{
PENGEMBANGAN MEDIA PEMBELAJARAN INTERAKTIF PADA PEMBELAJARAN PPKN MATERI GLOBALISASI DI SDN GONDANGDIA O1 PAGI JAKARTA PUSAT
}

\author{
Yuliawati \\ Universitas Negeri Jakarta \\ Yuliaawati7@gmail.com
}

\begin{abstract}
Abstrak
Penelitian ini bertujuan untuk menghasilkan media berupa media pembelajaran interaktif pada pembelajaran Pendidikan Pancasila dan Kewarganegaraan materi pembelajaran globalisasi kelas VI sekolah dasar. Metode penelitian yang digunakan dalam penelitian ini adalah penelitian dan pengembangan (R\&D) dengam model pengembangan ADDIE (Analisys, Design, Development, Implementation, and Evaluatuion). Responden dalam penelitian ini terdiri dari ahli materi, ahli media, dan ahli bahasa. Dikarenakan adanya pandemi covid-19, uji coba pengguna hanya dapat dilaksanakan pada uji coba one to one sampai dengan uji coba small group yang terdiri dari 3 orang uji coba pengguna one to one dan 6 orang uji coba pengguna small group dengan menggunakan siwa kelas VI yang berdomisili dengan peneliti. Teknik pengumpulan data yang digunakan dalam penelitian ini adalah wawancara, observasi, dan kuisioner. Hasil uji coba media pembelajaran interaktif kepada para ahli memperoleh nilai 87,5\% dari ahli materi, 95\% dari ahli bahasa, dan 96,6\% dari ahli media. Hasil dari penilain ketiga ahli tersebut memperoleh rata-rata $93,03 \%$. Sedangkan dalam uji coba pengguna one to one memperoleh nilai $90 \%$, dan uji coba pengguna small group memperoleh $83,3 \%$. Hal ini memnunjukan bahwa media pembelajaran interaktif memperoleh nilai Sangat Baik (SB) dengan rentang skor 75\%-100\% sehingga layak digunakan sebagai media pembelajaran Pendidikan Pancasila dan Kewarganegaraan Tema 4 "Globalisasi” Subtema 1"Globalisasi Disekitarku" kelas VI Sekolah Dasar.
\end{abstract}

Kata Kunci: Media Pembelajaran Interaktif, Pendidikan Pancasila dan Kewarganegaran, Materi Globalisasi.

\begin{abstract}
This study aims to produce media in the form of interactive learning media in Pancasila and Citizenship Education learning materials for globalization class VI elementary schools. The research method used in this research is research and development (R\&D) with the ADDIE development model (Analysis, Design, Development, Implementation, and Evaluatuion). Respondents in this study consisted of material experts, media experts, and linguists. Due to the COVID-19
\end{abstract}


pandemic, user trials can only be carried out on a one to one trial up to a small group trial consisting of 3 one to one user trials and 6 small group user trials using class VI students who domiciled with the researcher. Data collection techniques used in this study were interviews, observations, and questionnaires. The results of the trial of interactive learning media to experts obtained a score of $87.5 \%$ from material experts, $95 \%$ from linguists, and $96.6 \%$ from media experts. The results of the assessment of the three experts obtained an average of 93.03\%. Meanwhile, in the one-to-one user trial, the score was $90 \%$, and the small group user trial received $83.3 \%$. This shows that the interactive learning media gets a very good score (SB) with a score range of $75 \%-100 \%$ so it is suitable to be used as a learning medium for Pancasila and Citizenship Education Theme 4 "Globalization" Subtheme 1

"Globalization Around Me" Grade VI Elementary School

Keywords: Interactive Learning Media, Pancasila and Citizenship Education, Globalization Materials.

\section{PENDAHULUAN}

Kemajuan teknologi yang berkembang pesat dalam dunia pendidikan sangat berpengaruh terhadap proses pembelajaran. Pembelajaran atau proses belajar mengajar merupakan suatu proses interaksi (hubungan timbal balik antara guru dan peserta didik). Pembelajaran merupakan bagian dari pendidikan, yang di dalamnya ditunjang oleh berbagai unsur pembelajaran antara lain tujuan, materi pelajaran, sarana prasarana, situasi atau kondisi belajar, media pembelajaran, lingkungan belajar, metode pembelajaran.

Peserta didik akan belajar sambil menggunakan kecanggihan dan perkembangan teknologi dengan penggunaan teknologi dalam bentuk smartphone ini juga dapat menjadikan pengunaan smartphone oleh peserta didik menjadi lebih bermanfaat dan dengan begitu proses pembelajaran yang peserta didik temui akan sangat menyengkan, sehingga kekhawatiran guru ataupun orang tuan dalam penggunaan media pembelajaran berupa smarphone ini dapat dijadikan sebuah sarana penunjang pembelajaran peserta didik yang dapat menjadi kegiatan positif.

Berdasarkan hasil wawancara peserta didik kelas VI SDN Gondangdia 01 Pagi Jakarta Pusat, didapatkan informasi tentang analisis kebutuhan bahwa pada saat proses pembelajaran pendidikan pancasila dan Kewarganegaraan (PPKn) khususnya materi tentang globalisasi, peserta didik masih merasa kesulitan dalam memahami dengan baik materi tersebut. Peserta didik juga mengaku bahwa masih membutuhkan media pembelajaran lain selain buku untuk memahami pembelajaran PPKn, juga belum banyaknya media yang digunakan pada materi pembelajaran globalisasi dan media 
pembelajaran yang digunakan hanya berupa buku, PowerPoint, dan video pembelajaran saja. Peserta didik juga setuju bahwa akan lebih menyenangkan dan lebih mudah memahami pembelajaran PPKn dengan menggunakan media interaktif berbentuk aplikasi yang dapat di unduh pada smartphone android.

Media pembelajaran adalah semua bentuk perantara fisik yang didesain secara terencana untuk menyampaikan informasi dan membangun interaksi. Peralatan fisik yang dimaksud mencakup benda asli, bahan cetak, audio, audio-visual, multimedia, dan web. Peralatan tersebut harus dirancang dan dikembangkan secara sengaja agar sesuai dengan kebutuhan peserta didik dan tujuan pembelajaran (Yaumi, 2018). Media juga merupakan alat yang dapat membantu proses belajar mengajar yang berfungsi memperjelas makna pesan yang disampaikan sehingga tujuan pembelajaran dengan lebih baik dan sempurna (Cecep \& Daddy, 2020).

Media pembelajaran interaktif yaitu media yang meminta pembelajaran mempraktikan suatu keterampilan dan menerima balik (Sri Anitah, 2012). Media pembelajaran interaktif adalah suatu media yang dilengkapi oleh alat pengontrol yang dapat dioperasikan oleh pengguna, sehingga pengguna dapat memilih apa yang dapat dikehendaki untuk proses selanjutnya (Daryanto, 2013). Media pembelajaran interaktif adalah suatu sistem penyampaian pengajaran yang menyajikan materi video rekaman dengan pengendalian komputer kepada penonton (siswa) yang tidak hanya mendengar dan melihat video dan suara, tetapi juga memberikan respon yang aktif, dan respon itu yang menentukan kecepatan dan sekuensi penyajian (Arsyad, 2017).

Pendidikan Kewarganegaraan adalah pendidikan yang mengingatkan kita akan pentingnya nilai-nilai hak dan kewajiban seorang warga negara, sehingga segala sesuatu yang dilakukan seseuai dengan tujuan dan cita-cita bangsa dan tidak menyimpang dari apa yang diharapkan (Ismail dan Hartanti, 2020). Pendidikan kewarganegaraan juga merupakan pendidikan demokrasi yang bertujuan untuk mempersiapkan warga masyarakat berpikir kritis dan bertindak demokrasi, melalui aktivitas menanamkan kesadaran kepada generasi baru, tentang kesadaran bahwa demokrasi adalah bentuk kehidupan masyarakatyang paling menjamin hak-hak masyarakat (Saidurrahman dan Arifiansyah, 2018).

Berdasarkan data yang didapat dari observasi awal pada kelas VIB SDN Gondangdia 01 Pagi Jakarta Pusat yang dijadikan sempel untuk memperoleh data-data awal melalui wawancara, siswa didapati saat pembelajaran masih merasa kesulitan dalam memahami dengan baik materi pembelajaran PPKn, serta siswa masih membutuhkan media pembelajaran lain selain buku untuk memahami pembelajaran PPKn, juga belum banyaknya media yang digunakan pada materi pembelajaran globalisasi dan media pembelajaran yang digunakan hanya berupa buku, PowerPoint, dan video pembelajaran saja. 
Selanjutnya berdasarkan hasil observasi yang dilakukan di kelas VI, hampir semua peserta didik memiliki gadget berupa smartphone atau telpon seluler. Tetapi banyak diantara mereka yang menggunakan smartphone hanya digunakan untuk bermain game, dan sosial media. Guru pun menggunakan smartphone hanya digunakan sebagai sarana penunjang pembelajaran untuk mencari informasi di internet berkaitan dengan materi pembelajaran.

Media interaktif ini dapat di jadikan sarana pembelajaran sebab sangat efektif dan semakin mudah buat anak. generasi sekrang sudah hampir dekat dengan segela macam gadget, sehingga seolah menjaditrend masa kini dalam kegiatan pembelajaran yang interaktif.

Dari hasil uraian di atas, maka peneliti tertarik untuk mengembangkan media pembelajaran yaitu media pembelajaran interaktif yang peneliti yakini dapat memberi pengaruh baik kepada guru dan peserta didik. Penelitian yang akan dikembangkan yaitu "Pengembangan Media Pembelajaran Inateraktif Pada Pembelajaran PPKn Materi Globalisasin Kelas VI Sekolah Dasar”

\section{METODE}

Penelitian yang dilakukan oleh peneliti menggunakan metode penelitian dan pengembangan (R\&D). Metode penelitian dan pengembangan adalah metode yang digunakan untuk menghasilkan suatu pengembangan produk tertentu dan menguji kelayakan atau keefektivitasan produk tersebut. Penelitian ini menggunakan metode penelitian dan pengembangan ADDIE. Metode penelitian dan pengembangan dengan menggunakan ADDIE yang merupakan metode yang efektif digunakan dalam kondisi dengan adanya pandemic Covid-19 yang saat ini sedang terjadi dan tidak tahu kapan akan berakhir. Pada penelitian ini dibagi menjadi 5 tahapan yaitu (1) analysis, (2) design, (3) development, (4) implementation, dan (5) evaluation.

Tahap pertama yaitu analisis, pada tahap ini peneliti melakukan analisis kebutuhan untuk mengidentifikasi masalah, melakukan analisis tugas melalui wawancara. Melalui analisis kebutuhan peneliti dapat menentukan apa saja masalah yang ada dalam pembelajaran dan yang dibutuhkan. Selain itu, analisis kebutuhan dilakukan untuk menentukan karekteristik audience (peserta didik), media pembelajaran yang biasa digunakan, dan medi pembelajaran yang dibutuhkan. Tahap selanjutnya yaitu menentukan tujuan pembelajaran (target audince (peserta didik), dan sumber daya yang dibutuhkan). Menanggapi kebutuhan media pembelajaran yang dibutuhkan oleh peserta didik, dan hasil yang diinginkan dari penyelesain yang sukses.

Tahap kedua yaitu design, Tahapan kedua yaitu desain, pada tahapan ini akan ditentukan kerangka konseptual desain mengenai media pembelajaran itu sendiri baik 
secara kemasannya dan mengenai isi dari media pembelajaran itu sendiri yang meliputi instrumen-instrumennya.

Tahapan ketiga yaitu development atau pengembangan, Tahap ini merupakan proses mewujudkan rancangan yang telah dibuat yaitu: 1) sumber, terdiri dari a) pra produksi (pada tahap pra produksi peneliti menentukan latar belakang (backgroud), ikon menu tampilan utama, b) produksi (Pada bagian produksi, peneliti menginput bahan-bahan berupa media pembelajaran interaktif seperti (materi pelajaran, video pembelajaran, soal latihan, permainan, evaluasi, petunjuk penggunaan media, dan informasi), c) pasca produksi (Pada tahap pasca produksi, peneliti melakukan preview produk untuk menguji kesiapan dan kelayakan produk untuk digunakan).

Tahap keempa yaitu tahap implementation, pada tahap ini setelah melakukan pengembangan, media pembelajaran interaktif yang telah di uji coba oleh ahli materi, ahli bahasa, dan ahli media diperbaiki sesuai dengan saran dan masukan dari para ahli. Pada tahap ini media pembelajaran di uji coba kepada pengguna dengan beberapa tahap yaitu one to one berjumlah 3 siswa kelas VI SD, small group berjumlah 6 siswa VI SD, dengan memberikan kuisioner.

Tahapan kelima yaitu tahapan evaluation, setelah pengembangan media pembelajaran interaktif selesai maka akan dilakukan evaluasi formatif untuk menentukan apakah kualitas media pembelajaran memenuhi standar yang ditetapkan dalam fase desain. Evaluasi ini dilakukan untuk memastikan agar produk tersebut sudah siap dan layak untuk diimplementasikan yaitu dengan melakukan validasi ahli. Validasi ahli dilakukan oleh media berjumlah 1 orang, ahli bahasa berjumlah 1 orang, dan ahli materi berjumlah 1 orang. Pengumpulan data yang didapat oleh peneliti didapatkan dengan cara observasi, wawancara , dan kuesioner.

Teknik evaluasi pada penelitian ini menggunakan teknik analisis kualitatif dan kuantitatif. Data kuantitatif pada penelitian ini merupakan pemaparan hasil produk pengembangan bahan ajar berbasis komik digital interaktif melalui angket atau kuesioner. Jadi pada data kuantitatif (data angka) dibutuhkan data dari hasil angket penilaian terhadap produk. Data kuantitatif untuk menguji tingkat kelayakan dan tingkat efektifitas produk.

Sedangkan, data kualitatif pada penelitian ini yaitu merupakan data verbal (data non angka) masukkan validator pada tahap validasi, seperti masukkan kritik atau komentar dari ahli media, ahli materi, dan ahli bahasa. Data kualitatif lebih digunakan untuk menyempurnakan produk. Teknik analisis data kualitatif dapat dilakukan dengan cara berikut: (1) Mengumpulkan data yang diperoleh dari lembar observasi, (2) Menganalisis dan menyimpulkannya sebagai acuan untuk produk yang dikembangkan peneliti apakah sudah bisa diimplementasikan atau harus direvisi kembali. 


\section{HASIL PENELITIAN DAN PEMBAHASAN}

Data uji coba hasil penelitian pengembangan berdasarkan model pengembangan ADDIE adalah sebagai berikut:

\section{Analysis}

Pada tahap awal ini peneliti menganalisis kebutuhan Sumber daya yang dibutuhkan (isi,teknologi,fasilitas, dan manusia) dan metode pengiriman potensial ditentukan. Pada tahap ini peneliti melakukan analisis kebutuhan untuk mengidentifikasi masalah, melakukan analisis tugas melalui wawancara. Melalui analisis kebutuhan peneliti dapat menentukan apa saja masalah yang ada dalam pembelajaran dan yang dibutuhkan. Selain itu, analisis kebutuhan dilakukan untuk menentukan karekteristik audience (peserta didik), media pembelajaran yang biasa digunakan, dan medi pembelajaran yang dibutuhkan.

Sasaran penelitian ini didapatkan melalui wawancara analisis peneliti yaitu: a) Proses pembelajaran PPKn materi globalisasi di kelas VI sekolah dasar, b) Media yang digunakan pada pembelajaran PPKn materi globalisasi di kelas VI sekolah dasar, c) Permasalahan dalam pembelajaran PPKn materi globalisasi pada kelas VI sekolah dasar, e) Karekteristis siswa kelas VI sekolah dasar. Tahap selanjutnya yaitu menentukan tujuan pembelajaran (target audince (peserta didik), dan sumber daya yang dibutuhkan).

\section{Design}

Pada tahap ini peneliti mempelajari masalah yang ditemukan pada saat melakukan analisis kemudia menentukan alternatif atau solusi dari pemecahan masalah yang diidentifikasi dengan membuat rancangan produk yang akan dikembangkan yaitu media pembelajaran interaktif. Dalam membuat rancanga media pembelajaran interaktif disesuiakan dengan pembelajaran PPKn pada pembelajaran globalisasi di kelas VI sekolah dasar peneliti memilih tema yang akan dijadikan acuan pengembangan Media Pembelajaran Interaktif beserta dengan tujuan pembelajarannya.

Kemudian mementukan strategi pembelajaran dengan membangun tautan yang jelas diantara isi media dengan tujuan pembelajaran, dan memperkenalkan konten/isi dan kegiatan pembelajaran dalam urutan yang logis yang mendukung konstruksi pengetahuan peserta didik. Media Pembelajaran Interaktif yang dikembangkan disesuaikan dengan Tema dalam pembelajaran di kelas VI. Tema yang dipilih yaitu tema 4 "Globalisasi" subtema 1 "Globalisasi Disekitarku" pembelajaran 2,4, dan 6.

Setelah menentukan strategi pembelajaran, maka peneliti menentukan strategi pengujian dengan memberikan umpan balik tentang kemajuan peserta didik dalam memenuhi tujuan pembelajaran yang ditetapkan. Dalam membuat rancangan media pembelajaran interaktif, peneliti juga membuat umpan balik untuk mengetahui pemahaman siswa mengenai isi pada media pembelajaran yaitu dengan merancang tes evaluasi.

Setelah menentukan strategi pembelajaran, maka peneliti menentukan strategi pengujian dengan memberikan umpan balik tentang kemajuan peserta didik dalam 
memenuhi tujuan pembelajaran yang ditetapkan. Dalam membuat rancangan media pembelajaran interaktif, peneliti juga membuat umpan balik untuk mengetahui pemahaman siswa mengenai isi pada media pembelajaran yaitu dengan merancang tes evaluasi.

\section{Development}

Tahap ini merupakan proses mewujudkan rancangan yang telah dibuat. Ada beberapa langkah yang harus dilakukan agar produk yang dikembangkan dapat di implementasikan kepada peserta didik yaitu:

Sumber, yang terdiri dari a) pra produksi (pada tahap pra produksi peneliti menentukan latar belakang (backgroud), ikon menu tampilan utama, b) produksi (Pada bagian produksi, peneliti menginput bahan-bahan berupa media pembelajaran interaktif seperti (materi pelajaran, video pembelajaran, soal latihan, permainan, evaluasi, petunjuk penggunaan media, dan informasi), c) pasca produksi (Pada tahap pasca produksi, peneliti melakukan preview produk untuk menguji kesiapan dan kelayakan produk untuk digunakan).

Validasi uji ahli materi mendapatkan jumlah skor 35 dari skor maksimal 40 sehingga termasuk kategori Sangat Baik (SB). Sedangkan, data kualitatif didapat berdasarkan kritik dan saran dari ahli media sebagai berikut: a) aplikasi pembelajaran digunakan sesuai dengan kegiatan pembelajaran.

Validasi uji ahli bahasa mendapatkan jumlah skor 38 dari skor maksimal 40 sehingga termasuk kategori Sangat Baik (SB). Sedangkan, Data kualitatif didapat berdasarkan kritik dan saran dari ahli media sebagai berikut: a) Untuk melakukan perbaikan media pada warna tulisan yang kurang tepat.

Validasi uji ahli media mendapatkan jumlah skor 58 dari skor maksimal 60 sehingga termasuk kategori Sangat Baik (SB). Sedangkan, data kualitatif didapat berdasarkan kritik dan saran dari ahli media sebagai berikut: a) menambahkan intro sebelum masuk ke dalam menu utama.

\section{Implementation}

Tahapan uji coba terhadap siswa dilakukan guna menunjukkan bahwa pengembangan media pembelajaran interaktif pada pembelajaran PPKn materi globalisasi di kelas VI Sekolah Dasar (SD) ini efektif dan layak digunakan dalam proses pembelajaran.

a) Hasil uji coba One to One Evaluation

Evaluasi tahap one to one merupakan tahap uji coba media yang dilaksanakan dengan melibatkan tiga siswa kelas VI yang ada di sekitar rumah peneliti. Uji coba ini dilakukan dengan tujuan mengetahui kelayakan pada media pembelajaran yang sudah dikembangkan untuk mengetahui keefektivan siswa dan kelayakan pada pengembangan media pembelajaran interaktif itu sendiri. Media pembelajaran akan diketahui keberhasilan dan kelayakannya melalui kuesioner yang diisi oleh siswa kelas VI Sekolah Dasar (SD) 
setelah menggunakan media pembelajaran yang dikembangkan. Hasil rekapitulasi penilaian yang diperoleh uji pengguna one to one yang terdiri dari tiga orang siswa dengan persentasi sebesar 90\% bila dideskripsikan maka termasuk kategori Sangat Baik (SB) dan layak digunakan.

Data kualitatif didapatkan dari hasil kolom saran yang telah diisi oleh siswa yang diuji cobakan juga berdasarkan pengamatan peneliti. Siswa memahami penggunaan dan materi pembelajaran media pembelajaran interaktif yang telah mereka gunakan. Hal ini terlihat pada saat mereka menggunakan dan mengerjakan tes evaluasi yang terdapat dalam media pembelajaran interaktif. Dengan menggunakan media pembelajaran interaktif ini, siswa mengerti dan memahami pembelajaran PPKn materi globalisasi di kelas VI.

b) Hasil uji coba Small Group

Pada uji coba Small Group yang melibatkan lima orang siswa kelas VI Sekolah Dasar (SD). Uji coba small group ini merupakan tahap uji coba ke 2 yang dilaksanakan pada hari Kamis 22 April 2021. Hasil rekapitulasi penilaian yang diperoleh uji pengguna small group yang terdiri dari enam orang siswa dengan persentasi sebesar 83,3\% bila dideskripsikan maka termasuk kategori Sangat Baik (SB) dan layak digunakan.

Berdasarkan kolom saran pada kuesioner yang peneliti sudah sediakan, terdapat saran dari siswa kelas VI yang mengatakan bahwa media pembelajaran interaktif dalam penggunaanya siswa memahami penggunaan media pembelajaran interaktif dan materi yang ada pada media pembelajaran interaktif. Hal ini terlihat pada saat mereka menggunakan media pembelajaran interaktif yang sudah di unduh di smartphone android masing-masing, siswa terlihat antusias dan senang menggunakan media pembelajaran interaktif karena tidak hanya terdapat materi pembelajaran saja tetapi juga terdapat permaianan yang beragam, terdapat gambar-gambar yang menjelaskan materi pembelajaran, dan terdapat video pembelajaran.

\section{Evaluation}

Tahap evaluasi merupakan tahapan terakhir dalam model ADDIE, pada tahap ini peneliti meninjau kembali evaluasi yang sudah dilakukan dengan melibatkan 1 ahli media, 1 ahli bahasa, 1 ahli materi, dan siswa yang berguna untuk memperbaikki pengembangan bahan ajar agar lebih layak.

Media pembelajaran interaktif ini merupakan media pembelajaran inetaraktif yang dapat di unduh dengan smartphone android yang di dalam nya terdapat berabagi menu pilihan berupa menu utama yaitu menu materi, menu permainan, menu evaluasi, menu petunjuk penggunaan, dan menu informasi. Media pembelajaran interaktif ini dikembangkan untuk siswa kelas VI sekolah dasar. Media pembelajaran interaktif ini dibuat bersadarkan kebutuhan siswa yang diperoleh dari hasil wawancara pada saat peneliti melakukan analisis kebutuhan dan pada saat peneliti melakukan observasi pembelajaran di kelas. 
Media pembelajaran interaktif ini menyajikan suatu media dalam bentuk aplikasi android yang dapat di gunakan pada smartphone android. Media pembelajaran ini terdapat beberapa tanpilan menu pilihan yang di dalam nya terdapat materi pembelajaran, gambargambar ilustrasi yang menjelaskan materi pembelajaran, video pembelajaran, latihan soal evaluasi dan permaian yang terdiri dari jenis permaianan yaitu permaianan menyusun puzzle, permaian maze, dan permainan memori test. Media pembelajaraninteraktif yang dikembangkan peneliti diadaptasi dari Buku Tema 4 "Globalisasi”, Subtema 1 "Globalisasi Disekitarku" dan disesuaikan dengan muatan pembelajaran Pendidikan Pancasila dan Kewarganegaraan pada kelas VI Sekolah Dasar.

Pemilihan tema dan subtema tersebut bertujuan agar konsep dari cerita yang akan dikembangkan lebih jelas dan terstruktur.Media pembelajaran interaktif yang disampaikan bertemakan pembelajaran globalisasi. Latar yang terdapat dalam media pembelajaran inetarktif adalah globalisasi yang ada di lingkungan sekitar. Tampilan anatar menu dan slide tampilan dalam media pembelajaran interaktif saling berkesinambungan.

Dalam media pembelajaran media interaktif ini terdapat juga permaianan yang terdiri dari tiga jenis permainan yang berbeda yaitu permaian menyusun puzzle, permaian maze, dan permaianan memori test yang masih berhubungan dengan materi pembelajaran globalisasi, dan di dalam media pembelajaran terdapat menu tes evaluasi yang yang dikemas dalam dalam bentuk soal pilihan ganda siswa diminta untuk memilih jawaban yang paling benar.

Media pembelajaran ini dikembangkan dengan menggunakan model Pengembangan ADDIE dengan menyesuaiakan tahap-tahap model pengembangan tersebut. Tahapantahapan model pengembangan ADDIE yaitu analisys (analisis), design (desain/perencanaan), development (pengembangan), implementation (implementasi), dan evaluation (evaluasi).

Dalam pengembangan media pembelajaran interaktif ini, tahap pertama yang dilakukan adalah melakukan wawancara guru kelas dan observasi pembelajaran yang merupakan bagian analisis kebutuhan. Selanjutnya peneliti menentukan tema, subtema, tujuan pengembangan, manfaat pengembangan, desain/bentuk fisik media, pemilihan latar belakang (background), ikon menu tampilan, pemilihan gambar, warna, tulisan, dan model pengembangan yang disesuaikan dengan karakteristik siswa kelas VI sekolah dasar. Penentuan kompenen tersebut dijadikan sebagai acuan dalam pengembangan agar lebih jeals dan terkonsep.

Media pembelajaran interaktif yang dikembangkan oleh peneliti memiliki beberapa kelebihan sebagai berikut: 1) Merupakan media pembelajaran yang menarik dan cocok digunakan dalam pembelajaran PPKn materi globalisasi di kelas VI sekolah dasar. 2) Merupakan media pembelajaran interaktif dalam bentuk aplikasi yang dapat di unduh menggunakan smartphone android. 3) Mudah digunakan karena tidak memerlukan 
koneksi data seluler (offline). 4) Bahasanya mudah dipahami dan sesuai dengan karakteristik siswa kelas VI sekolah dasar. 5) Dilengkapi gambar dan video pembelajaran yang menerangkan materi pembelajaran. 6) Dilengkapi permainan yang terdiri dari tiga jenis permainan yang berbeda yaitu permainan menyusun puzzle, permainan maze, dan permainan memori test. 7) Terdapat piagam pengharga sebagai apresiasi kepada siswa karena telah menggunakan media pembelajaran interaktif yang dapat diunduh oleh siswa. 8) Membuat proses pembelajaran lebih menyenangkan. 9) Media pembelajaran interaktif ini dapat digunakan kapan saja dan di mana saja. 10) Desiain tampilan dan menu pilihan media pembelajaran disesuaikan dengan karakteristik media pembelajaran untuk siswa kelas VI sekolah dasar.

Kekurangan media pembelajaran interaktif sebagai berikut: 1) Media pembelajaran interaktif ini hanya memuat materi pembelajaran yang ada pada buku tematik yaitu Tema 4 "Globalisasi" dan Subtema 1 "Globalisasi Disekitarku" saja. 2) Media pembelajaran ini hanya dapat digunakan perangkat smartphone android saja

Pengembangan media pembelajaran interaktif pada pembelajaran PPKn materi globalisasi ini belum sepenuhnya sempurna, pada penelitian peneliti memiliki keterbatasan penelitian yaitu sebagai berikut: 1) Peneliti tidak melakukan uji efektifitas media pembelajaran interaktif ini. 2) Peneliti tidak melaksanakan evaluasi sumatif dalam penelitian. 3) Dikarenakan kondisi pandemi Covid - 19 peneliti tidak melakukan uji pengguna secara maksimal melainkan hanya pada sampai tahap uji small group.

\section{KESIMPULAN}

Peneliti mengembangkan media pembelajaran interaktif pada pembelajaran PPKn materi globalisasi. Media ini berlandaskan pada Tema 4 "Globalisasi" Subtema 1 "Globalisasi Disekitarku" Kelas VI Sekolah Dasar. Media pembelajaran interaktif digunakan sebagai media pada muatan pembelajaran Pendidikan Pancasila dan Kewarganegaran. Media pembelajaran interaktif ini memuat pembelajaran globalisasi yang ada di sekitar lingkungan siswa.

Penelitian pengembangan ini menggunakan model pengembangan ADDIE dengan tahap pengembangan sebagai berikut: 1) Analysis (analisis), ada tahap ini peneliti melakukan analisis kebutuhan untuk mengidentifikasi masalah, melakukan analisis tugas melalui wawancara. Melalui analisis kebutuhan peneliti dapat menentukan apa saja masalah yang ada dalam pembelajaran dan yang dibutuhkan. Selain itu, analisis kebutuhan dilakukan untuk menentukan karekteristik audience, media pembelajaran yang biasa digunakan, dan medi pembelajaran yang dibutuhkan.

Sasaran penelitian ini didapatkan melalui wawancara analisis peneliti yaitu: 1)Proses pembelajaran PPKn materi globalisasi di kelas VI sekolah dasar. 2) Media yang digunakan pada pembelajaran PPKn materi globalisasi di kelas VI sekolah dasar. 3) 
Permasalahan dalam pembelajaran PPKn materi globalisasi pada kelas VI sekolah dasar, 4) Karakteristis siswa kelas VI sekolah dasar.Tahap selanjutnya yaitu menentukan tujuan pembelajaran (target audince, dan sumber daya yang dibutuhkan). Menanggapi kebutuhan media pembelajaran yang dibutuhkan oleh peserta didik, dan hasil yang diinginkan dari penyelesain yang sukses. 2) Design (perencanaan), pada tahap ini peneliti mempelajari masalah yang ditemukan pada saat melakukan analisis kemudia menentukan alternatif atau solusi dari pemecahan masalah yang diidentifikasi dengan membuat rancangan produk yang akan dikembangkan yaitu media pembelajaran interaktif. Dalam membuat rancanga media pembelajaran interaktif disesuiakan dengan pembelajaran PPKn pada pembelajaran globalisasi di kelas VI sekolah dasar peneliti memilih tema yang akan dijadikan acuan pengembangan Media Pembelajaran Interaktif beserta dengan tujuan pembelajarannya.

Kemudian mementukan strategi pembelajaran dengan membangun tautan yang jelas diantara isi media dengan tujuan pembelajaran, dan memperkenalkan konten/isi dan kegiatan pembelajaran dalam urutan yang logis yang mendukung konstruksi pengetahuan peserta didik. Media Pembelajaran Interaktif yang dikembangkan disesuaikan dengan Tema dalam pembelajaran di kelas VI. Tema yang dipilih yaitu tema 4 "Globalisasi" subtema 1 "Globalisasi Disekitarku" pembelajaran 2,4, dan 6. Setelah menentukan strategi pembelajaran, maka peneliti menentukan strategi pengujian dengan memberikan umpan balik tentang kemajuan peserta didik dalam memenuhi tujuan pembelajaran yang ditetapkan. Dalam membuat rancangan media pembelajaran interaktif, peneliti juga membuat umpan balik untuk mengetahui pemahaman siswa mengenai isi pada media pembelajaran yaitu dengan merancang tes evaluasi. 3) Development (pengembangan).

Tahap ini merupakan proses mewujudkan rancangan yang telah dibuat. Ada beberapa langkah yang harus dilakukan agar produk yang dikembangkan dapat di implementasikan kepada peserta didik yaitu : 1) Sumber, yang terdiri dari a) pra produksi (pada tahap pra produksi peneliti menentukan latar belakang (backgroud), ikon menu tampilan utama, b) produksi (Pada bagian produksi, peneliti menginput bahan-bahan berupa media pembelajaran interaktif seperti (materi pelajaran, video pembelajaran, soal latihan, permainan, evaluasi, petunjuk penggunaan media, dan informasi), c) pasca produksi (Pada tahap pasca produksi, peneliti melakukan preview produk untuk menguji kesiapan dan kelayakan produk untuk digunakan). 4) Implementation (implementasi), Setelah melakukan pengembangan, media pembelajaran interaktif yang telah di uji coba oleh ahli materi, ahli bahasa, dan ahli media diperbaiki sesuai dengan saran dan masukan dari para ahli. Pada tahap ini media pembelajaran di uji coba kepada pengguna dengan beberapa tahap yaitu one to one, small group, dan field test dengan memberikan kuisioner. 5) Evaluation (evaluasi), setelah pengembangan media pembelajaran interaktif selesai maka akan dilakukan evaluasi formatif untuk menentukan apakah kualitas media pembelajaran memenuhi standar yang ditetapkan dalam fase desain. 
Evaluasi ini dilakukan untuk memastikan agar produk tersebut sudah siap dan layak untuk diimplementasikan yaitu dengan melakukan validasi ahli. Validasi ahli dilakukan oleh media, ahli bahasa, dan ahli materi.Dengan menggunakan langkah-langkah pengembangan ADDIE tersebut, peneliti hanya melakukan sampai dengan tahap Development (pengembangan) dikarenakan adanya pandemi covid-19, untuk evaluasi produk dalam penelitian ini melalui eveluasi formatif. Eveluasi ini dilakukan untuk memastikan agar produk tersebut sudah siap untuk diimplementasikan yaitu dengan melakukan validasi ahli yang terdiri dari ahli materi, ahli bahasa, dan ahli media.

Tahap evaluasi formatif ini melibatkan ahli materi, ahli bahasa, dan ahli media. Berdasarkan uji coba ketiga ahli tersebut, media pembelajaran interaktif pada pembelajaran PPKn materi globalisasi mendapatkan nilai yang berbeda dari ketiga ahli. Pada tahap uji ahli materi, media pembelajaran interaktif memperoleh nilai 87,5\% dan termasuk ke dalam kategori Sangat Baik (SB). Pada tahap uji ahli bahasa, media pembelajaran interaktif termasuk ke dalam kategori Sangat Baik (SB) dengan nilai 95\%. Sedangkan pada tahap uji ahli media, media pembelajaran interaktif termasuk ke dalam kategori Sangat Baik (SB) dengan nilai 96,6\%. Dari ketiga uji ahli tersebut, jika diakumulasikan berdasarkan tabel 3.8, hasil uji ketiga ahli pada media pembelajaran interaktif memperoleh rata-rata nilai 93,03\% dan termasuk ke dalam kategori Sangat Baik (SB) dengan rentang skor 75\%$100 \%$.

Selaian melalui tahap uji ahli, media pembelajaran interaktif juga diimplementasikan melalui tahap uji pengguna yang hanya dilakukan hanya sampai tahap uji coba pengguna small group dikarenakan kondisi pandemi Covid-19. Berdasarkan uji coba penguna one to one, media pembelajaran interaktif termasuk ke dalam kategori Sangat Baik (SB) dengan perolehan nilai 90\%. Sedangkan berdasarkan hasi uji coba penguna small group, media pembelajaran interaktif termasuk ke dalam kategori Sangat Baik (SB) dengan perolehan nilai 83,3\%. Berdasarkan tabel 3.8 media pembelajaran interaktif termasuk ke dalam kategori Sangat Baik (SB) dengan rentang skor 75\%-100\% dan layak digunakan pada pembelajaran Pendidikan Pancasila dan Kewarganegaraan Kelas VI Sekolah Dasar.

Dalam Pengembangan media pembelajaran interaktif dapat mempengaruhi beberapa aspek dari segi berikut: 1) Secara teoritik, Penelitian pengembangan ini dapat dijadikan sebagai acuan atau referensi bagi peneliti selanjutnya. penelitian pengembangan ini juga dapat menambahkan teori media pembelajaran interaktif dan produk media pembelajaran interaktif. 2) Secara praktis sebagai berikur : a) Bagi siswa, penelitian pengembangan ini dapat membantu dan mempermudah siswa dalam mengerti dan memahami pembelajaran Pendidikan Kewarganegaraan materi pembelajaran globalisasi serta membantu mempelajari materi pembelajaran dengan menggunakan hasil pengembangan media yang menarik.b) Bagi guru, media pembelajaran interaktif ini dapat 
Qufiawati

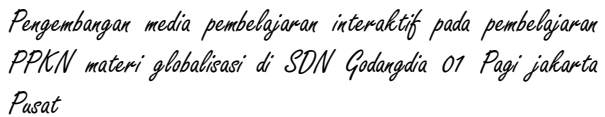

digunakan sebagai referensi media pembelajaran atau alat bantu pembelajaran serta dapat digunakan sebagai media pembalajaran lain kelas VI sekolah dasar. c) Bagi peneliti, penelitian pengembangan ini dibuat dengan harapan untuk melengkapi kekurangan pada media pembelajaran sebelumnya. Penelitian pengembangan ini juga dapat digunakan sebagai acuan apabila peneliti melakukan penelitian lanjutan yang berhubungan dengan penelitian pengembangan ini.

\section{DAFTAR PUSTAKA}

Yaumi Muhammad. (2018). Media dan Teknologi Pengajaran. Jakarta: PRENADA MEDIA, 2018.

Cecep, Darmawan Daddy. 2020. Pengembangan Media Pembelajaran, Jakarta: KENCANA.

Anita Sri. Media Pembelajaran. 2012. Surakarta: Yuma.

Daryanto. 2013. Media Pembelajaran. Jakarta: Rajawali Pers.

Arsyad Azhar. 2017. Media Pembelajaran. Jakarta: Rajawali Pers Awang.

Ismail dan Hartati Sri. 2020. Pendidikan Kewarganegaraan (Konsep Dasar Kehidupan Bebangsa dan Bernegara di Indonesia). (Jawa Timur : CV. Penerbit Qiara Media

Saidurrahman dan Arifiansyah. 2018. PENDIDIKAN KEWARGANEGARAAN. Jakarta : Kencana. 